\title{
OPTIMIZATION AND VALIDATION OF A DERIVATIZATION METHOD FOR ANALYSIS OF BIOGENIC AMINES IN WINES USING RP-HPLC-DAD
}

\author{
Krste Tašev ${ }^{1,2, *}$, Violeta Ivanova-Petropulos ${ }^{3}$, Marina Stefova ${ }^{2}$ \\ ${ }^{1}$ State Phytosanitary Laboratory, Blvd. Alexander the Great bb, 1000 Skopje, Republic of Macedonia \\ ${ }^{2}$ Institute of Chemistry, Faculty of Natural Sciences and Mathematics, Ss. Cyril and Methodius University, \\ Arhimedova 5, 1000 Skopje, Republic of Macedonia \\ ${ }^{3}$ Faculty of Agriculture, University Goce Delčev, Krste Misirkov bb, Štip, Republic of Macedonia \\ *tkrste@gmail.com
}

An analytical method for determination of the biogenic amines tryptamine, putrescine, histamine, phenylethylamine, tyramine, cadaverine, spermidine and spermine in red and white wines using precolumn derivatization with dansyl chloride (DnsCl) and reversed phase-high performance liquid chromatography with diode array detector (RP-HPLC-DAD) was developed and optimized. The concentration of $\mathrm{DnsCl}, \mathrm{pH}$, time of reaction and evaporation under nitrogen were tested and optimized. Best recoveries, ranging from 72 to $102 \%$ were obtained for all analyzed amines applying derivatization with $10 \mathrm{mg} / \mathrm{ml}$ of $\mathrm{DnsCl}$ for $1 \mathrm{~h}$ at $60^{\circ} \mathrm{C}$ and $\mathrm{pH}$ 9. The developed method showed excellent linearity with $R^{2}>0.99$ for all of the tested amines. The accuracy was checked with the standard addition method showing satisfactory recovery, good repeatability and reproducibility. The optimized and validated method was applied for the analysis of white and red wines from Macedonian origin, observing higher total amounts of biogenic amines in red wines. The content of the individual biogenic amines was below the maximal allowed concentration in all tested wines.

Keywords: wine; biogenic amines; HPLC; derivatization; dansyl chloride; validation

\section{ОПТИМИЗАЦИЈА И ВАЛИДАЦИЈА НА МЕТОД ЗА АНАЛИЗА НА БИОГЕНИ АМИНИ ВО ВИНА СО ПРИМЕНА HA RP-HPLC-DAD}

\begin{abstract}
Развиен е и оптимизиран аналитички метод за определување на биогените амини триптамин, путрескин, хистамин, фенилетиламин, тирамин, кадаверин, спермидин и спермин во црвени и бели вина со примена на претколонска дериватизација со дансилхлорид (DnsCl) и реверзно-фазна високоефикасна течна хроматографија со детектор со низа од диоди (RP-HPLCDAD). Концентрацијата на $\mathrm{DnsCl}, \mathrm{pH}$, времето на реакцијата и испарувањето со азот беа тестирани и оптимизирани. За сите анализирани амини беа постигнати најдобри аналитички приноси во граници од 70 до $102 \%$, применувајќи дериватизација со раствор од DnsCl со концентрација од 10 $\mathrm{mg} / \mathrm{ml}$, за време од $1 \mathrm{~h} \mathrm{на} 60^{\circ} \mathrm{C}$ и $\mathrm{pH}$ 9. Развиениот метод се карактеризира со одлична линеарност co $R^{2}>0.99$ за сите анализирани амини. Точноста на методот беше проверена со метод на стандарден додаток, при што беа добиени задоволителни вредности за аналитичкиот принос, добра повторливост и репродуцибилност. Оптимизираниот и валидиран метод беше применет за анализа на бели и црвени вина од македонско потекло, при што повисоки вредности на вкупните амини беа забележани во црвените вина. Во сите вина содржината на индивидуалните биогени амини беше пониска од максимално дозволената концентрација.
\end{abstract}

Клучни зборови: вино; биогени амини; HPLC; дериватизација; дансилхлорид; валидација 


\section{INTRODUCTION}

Biogenic amines are organic nitrogen compounds with low molecular weight whose presence plays a vital role in oenology because their presence at high levels in wine can lead to health prob-<smiles>NCCc1c[nH]c2ccccc12</smiles>

tryptamine (TRP)<smiles>NCCc1ccccc1</smiles>

2-phenylethylamine (PEA)<smiles>NCCCCN</smiles>

putrescine (PUT)<smiles>NCCCCCN</smiles>

cadaverine $(\mathrm{CAD})$ lems. The most important biogenic amines in wine are tryptamine (TRP), putrescine (PUT), histamine (HIST), phenylethylamine (PEA), tyramine (TYR), cadaverine (CAD), spermine (SPM), spermidine (SPD) [1-6]. The chemical structures of biogenic amines are presented in Figure 1.

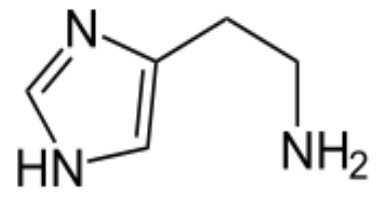

histamine (HIST)<smiles>NCCc1ccc(O)cc1</smiles>

tyramine (TYR)<smiles>NCCCCNCCCN</smiles>

spermidine (SPD)<smiles>NCCCNCCCCNCCCN</smiles>

Fig. 1. Chemical structures of biogenic amines

The upper limits of biogenic amines in wine are set at different levels in different countries. For example, the upper limit for histamine is $2 \mathrm{mg} / \mathrm{l}$ in Germany, 5 to $6 \mathrm{mg} / \mathrm{l}$ in Belgium, $8 \mathrm{mg} / \mathrm{l}$ in France, and $10 \mathrm{mg} / \mathrm{l}$ in Switzerland [7, 8].

Biogenic amines can be found in the grape must, but they can also be formed by yeast during alcoholic and malolactic fermentation, as well as during wine aging [9-11]. Sometimes, biogenic amines show correlation with the spoilage of wine and associate with other wine spoilage components for example butyric acid, lactic acid, acetic acid, ethyl acetate and diethyl succinate [4-7, 25]. An increase in the levels of biogenic amines in wines usually occurs towards the end of the malolactic fermentation (MLF) or during maturation, when lactobacilli and pediococci are the main culprits [6].

The health risks arising from the presence of biogenic amines are related to symptoms such as nausea, respiratory discomfort, hot flushes, cold sweat, palpitations, headaches, red rash, high or low blood pressure, intracerebral hemorrhage or even death $[9,12,16,17]$. The most problematic biogenic amine is histamine, which causes headaches, low blood pressure, heart palpitations, edema, vomiting and diarrhea [1, 18-20].

The challenge in the determination of biogenic amines is due to their low molecular weight, very low concentration [17, 21], low absorption in the UV-VIS wavelength region and the fact that they do not exhibit fluorescence. Therefore, pre- or post-column chemical derivatization using dansyl chloride (DnsC1) or $o$-phthalaldehyde (OPA) [17] is usually applied for their analysis by HPLC coupled to ultraviolet or fluorescence detectors [22]. Biogenic amines are usually determined by separation techniques like high performance liquid chromatography (HPLC), capillary electrophoresis (CE), and gas chromatography (GC) [9, 22-24]. These methods mainly involve spectrophotometric or fluorometric detection and/or determination with mass spectrometry (MS). At present, HPLC is 
the most commonly used technique because of its great versatility and is therefore an official technique for the analysis of histamine in foods (AOAC, Association of Official Analytical Chemists).

Since the presence of high amounts of biogenic amines in wines can lead to health problems, their determination is very important, using suitable methods for simultaneous determination of the most common representatives with suitable analytical performance. To the best of our knowledge, the analysis of biogenic amines has not been previously performed on Macedonian wines. Therefore, the aim of this work was: (1) to develop and optimize a pre-column derivatization method with dansyl chloride, followed by HPLC-DAD analysis and (2) to report, for the first time, data on the content of biogenic amines in Macedonian red and white wines.

\section{EXPERIMENTAL}

\subsection{Chemicals}

Standards of biogenic amines used in the study were: tryptamine, putrescine, cadaverine, spermine, spermidine, tyramine and histamine, provided by Sigma Aldrich (Munich, Germany) and 2-phenylethylamine, provided by Fluka (Munich, Germany). Acetonitrile and water (purity for HPLC) were from Carlo Erba (Cornaredo, Italy). Dansyl chloride (99.0\% purity) was from Sigma Aldrich (Lyon, France) and $\mathrm{Na}_{2} \mathrm{CO}_{3}$ (p.a.) from Merck - Alkaloid (Skopje, Macedonia). All other chemicals used were of analytical grade purity.

\subsection{Wine samples}

In total, 13 wines, 6 white (Muscat, Risling, Smederevka, Sauvignon Blanc, Žilavka, Chardonnay) and 7 red (Vranec, Cabernet Sauvignon, Kadarka, Kratošija, Merlot, Plavac, Pinot Noir) produced in the Tikveš wine region (latitude $41^{\circ} 25^{\prime}$ $57^{\prime \prime} \mathrm{N}$ and longitude $22^{\circ} 05^{\prime} 11^{\prime \prime} \mathrm{E}$ ) (Republic of Macedonia), vintage 2015, were analyzed. All wines were produced in vintage 2015 and kept at $4{ }^{\circ} \mathrm{C}$ before analysis.

\subsection{Sample preparation}

In this work, a simple direct derivatization of the biogenic amines using dansyl chloride (DnsCl) was applied [5, 16, 21] because this reagent allows reaction with primary and secondary amino groups, establishing very stable derivatives that are well retained on a $\mathrm{C} 18$ column and exhibit absorption in the UV region at $220 \mathrm{~nm}[9,16]$. For sample preparation, a volume of $500 \mu 1$ wine was added to $1000 \mu \mathrm{l}$ solution of previously prepared DnsCl $(20 \mathrm{mg} / \mathrm{ml})$, followed by the addition of 250 $\mu 1 \mathrm{Na}_{2} \mathrm{CO}_{3}$ solution $(0.4 \mathrm{M})$ to adjust the $\mathrm{pH}$ to 9 . Derivatization reaction was performed in a $15 \mathrm{ml}$ plastic test tube, which was placed in a water bath (Grant), at $60^{\circ} \mathrm{C}$ for $1 \mathrm{~h}$. Then, the sample was centrifuged at $3500 \mathrm{rpm}$ for $5 \mathrm{~min}$. The supernatant was transferred into another tube and evaporated to dryness using a nitrogen evaporator (Organomation $\mathrm{N}$-EVAP), heated at $40{ }^{\circ} \mathrm{C}$ during the evaporation. Dry wine residue was reconstituted in $500 \mu$ acetonitrile, shaken on a vortex for 5 min and ultrasonicated for $15 \mathrm{~min}$, followed by filtration with a 0.45 $\mu \mathrm{m}$ filter (Agilent PTFE). A volume of $10 \mu \mathrm{l}$ was injected into the HPLC-DAD system.

The derivatization agent $\mathrm{DnsCl}$ was prepared as follows: $1 \mathrm{~g}$ DnsCl was dissolved in $10 \mathrm{ml}$ acetone, due to the stability of the $\mathrm{DnsCl}$ in acetone. Each day, a volume of $2 \mathrm{ml}$ of this solution was dissolved in $10 \mathrm{ml}$ of acetonitrile and used for wine sample derivatization.

\subsection{Calibration curves}

Stock solutions $(1 \mathrm{mg} / \mathrm{ml})$ of each biogenic amine (tryptamine, 2-phenyethylamine, putrescine, cadaverine, spermine, spermidine, tyramine and histamine) were prepared in $0.1 \mathrm{M} \mathrm{HCl}$. For quantification, seven-point calibration curves were constructed in a range as shown in Table 1. Each calibration standard was prepared following the procedure for wine sample preparation, as described above (section 2.3).

\subsection{HPLC-DAD analysis}

A Varian Pro Star HPLC system (ternary pump model 230, autosampler model 410, PDA detector model 330 and Column valve module with thermostat model 500) (Palo Alto, CA, USA) was used in the study. Biogenic amines were analyzed with the Varian Microsorb 100-5 C18 column (250 $\mathrm{mm} \times 4.6 \mathrm{~mm} ; 5 \mu \mathrm{m})$ at $30^{\circ} \mathrm{C}$ for the separation, using water (solvent A) and acetonitrile (solvent B) at flow rate of $1 \mathrm{ml} / \mathrm{min}$. The proportions of solvent $\mathrm{B}$ were as follows: $0 \mathrm{~min}, 50 \% ; 10 \mathrm{~min}, 80$ $\%$; $25 \mathrm{~min}, 90 \%$; 27 to $30 \mathrm{~min}, 50 \% \mathrm{~B}$ (total run time: $30 \mathrm{~min}$ ). Monitoring and quantification of biogenic amines was performed at $220 \mathrm{~nm}$ and injection volume of the sample was $10 \mu \mathrm{l}$. The compound peaks were identified by their retention times, compared with the standards and the UVVIS spectra in the range between 200 and $300 \mathrm{~nm}$. 


\subsection{Statistical analysis}

Statistical treatment of the data for biogenic amines obtained after the HPLC analysis was performed, including calculation of mean, relative standard deviation, standard error and one-way ANOVA, with STATISTICA 6.0 software (Stat Soft Inc., USA).

\section{RESULTS AND DISCUSSION}

\subsection{Optimization of the HPLC method}

In order to develop a convenient, simple and rapid HPLC method for quantitative analysis of biogenic amines in wine, different HPLC columns with different lengths and particle sizes were used: the Perkin Elmer Brownlee C18 column $(150 \mathrm{~mm}$ $\times 4.6 \mathrm{~mm}, 5 \mu \mathrm{m})$ with spherical end caped particles; the Supleco LiChrosorb C18 column (250 $\mathrm{mm} \times 4.6 \mathrm{~mm}, 5 \mu \mathrm{m}$ ) with irregular particles, and the Varian Microsorb 100-5 C18 column (250 mm $\times 4.6 \mathrm{~mm}, 5 \mu \mathrm{m})$ with spherical particles. Separation of the analytes tryptamine, 2-phenyethylamine, putrescine, cadaverine, spermine, spermidine, tyramine and histamine performed on these three columns is presented in Figure 2.

The shortest run-time (total $22 \mathrm{~min}$ ) was achieved with the Perkin Elmer column (Fig. 2 A), using a faster gradient program (flow rate of 1 $\mathrm{ml} / \mathrm{min}$, gradient: $0 \mathrm{~min}, 50 \% \mathrm{~B} ; 8 \mathrm{~min}, 80 \% ; 18$ min, $90 \%$; 20 to 22 min $50 \%$ ), but satisfactory separation between cadaverine (peak 4) and histamine (peak 5) was not achieved using this column. The other two columns, from Supelco and Varian (Fig. 2 B and C) showed similar separation efficiency, presenting satisfactory resolution between all biogenic amines. Finally, the column from Varian was selected for further work due to the better response and elution time of the last compound, spermine. The gradient elution program was the one given in section 2.5. A chromatogram obtained from a real sample of red wine (Vranec) recorded at $220 \mathrm{~nm}$ is presented in Figure 3.

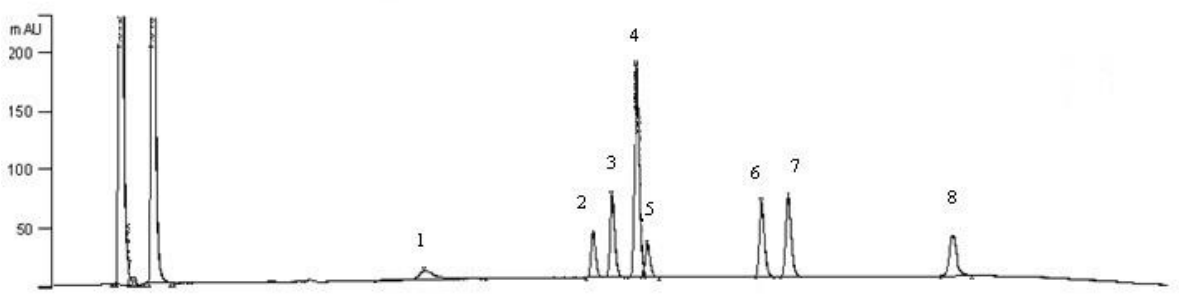

A)
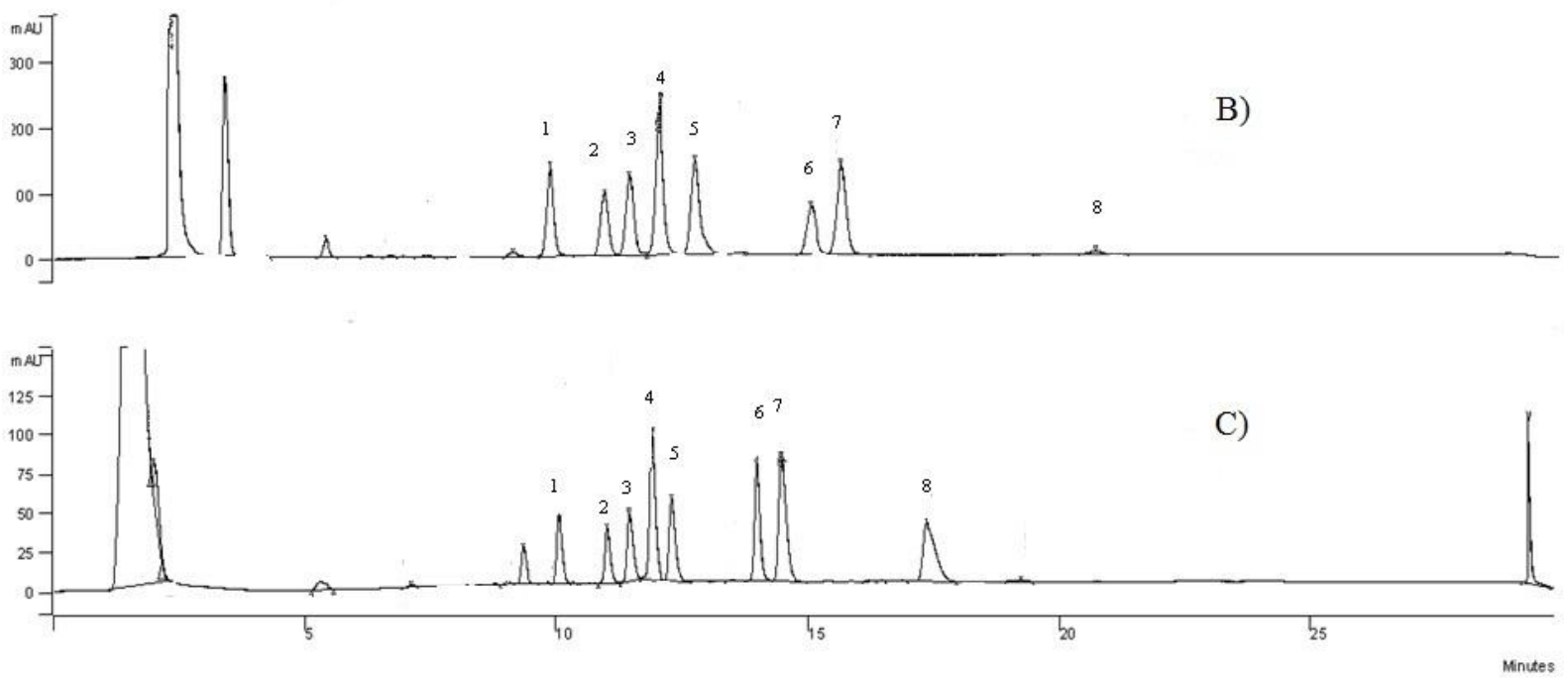

Fig. 2. HPLC chromatograms of standard solution of biogenic amines obtained at $220 \mathrm{~nm}$ with three columns: A) Perkin Elmer Brownlee column $150 \mathrm{~mm} \times 4.6 \mathrm{~mm}, 5 \mu \mathrm{m}$; B) Supleco LiChrosorb $250 \mathrm{~mm} \times 4.6 \mathrm{~mm}, 5 \mu \mathrm{m}$; C) Varian Microsorb 100-5 C18 $250 \mathrm{~mm} \times 4.6 \mathrm{~mm}, 5 \mu \mathrm{m}$. Gradient elution (described in the Material and methods) with water and acetonitrile, flow rate $1 \mathrm{ml} / \mathrm{min}, 10 \mu \mathrm{l}$ sample.

Peak numbers: 1 - tryptamine, 2 - 2-phenylethylamine, 3 - putrescine, 4 - cadaverine, 5 - histamine, 6 - tyramine, 7 - spermidine, 8 - spermine 


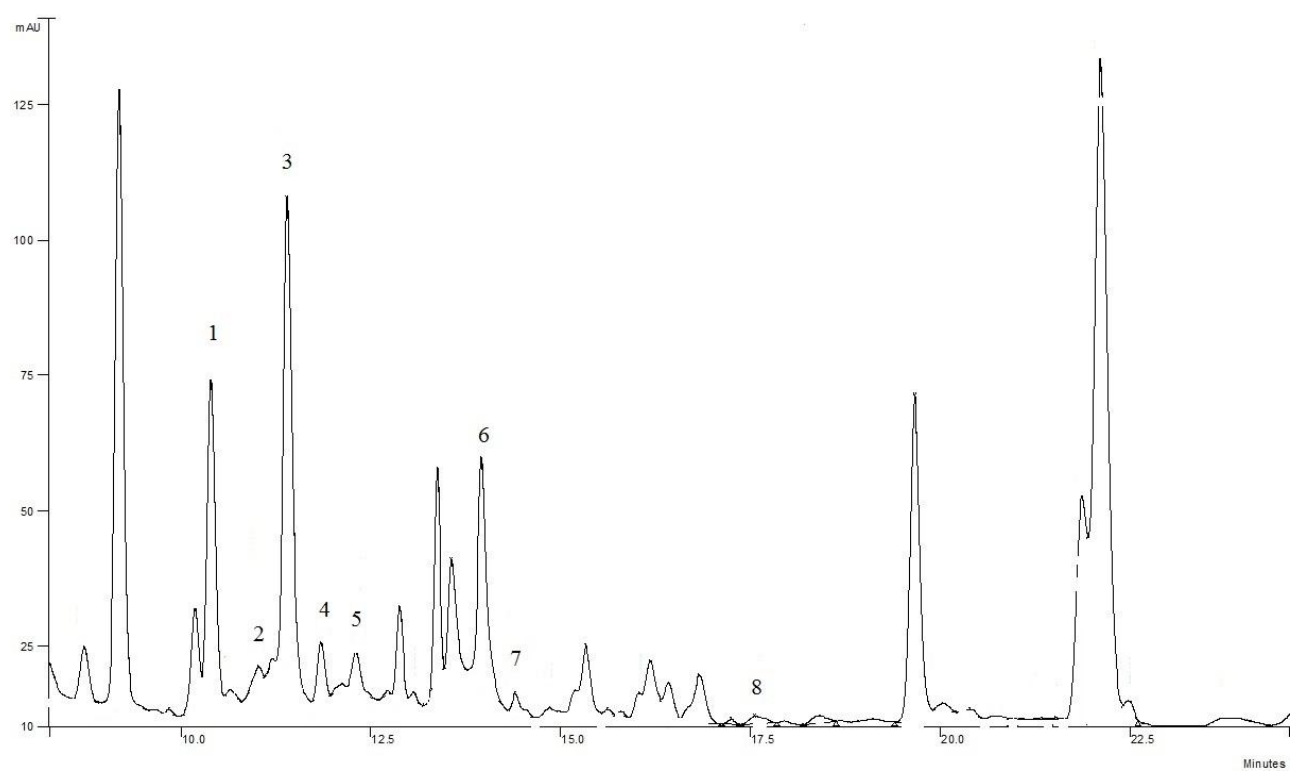

Fig. 3. HPLC chromatograms of biogenic amines in red wine obtained at $220 \mathrm{~nm}$ : on Varian Microsorb 100-5 C18 $250 \mathrm{~mm} \times 4.6 \mathrm{~mm}, 5 \mu \mathrm{m}$. Peak numbers: 1 - tryptamine,

2-2-phenylethylamine, 3 - putrescine, 4 - cadaverine, 5 - histamine, 6 - tyramine, 7 - spermidine, 8 - spermine

\subsection{Optimization of the derivatization conditions}

Biogenic amines are small and very polar molecules, which cannot be retained on $\mathrm{C} 18$ columns. Furthermore, amines do not exhibit satisfactory absorption in the visible or ultraviolet wavelength region and do not have any fluorescence. Therefore, derivatization is a necessary step for their analysis.

In this study, we used dansyl chloride $(\mathrm{DnsCl})$ as a derivatization reagent. In order to study the influence of the concentration of DnsCl, solutions with variable concentrations were prepared: $5,10,15,20$ and $25 \mathrm{mg} / \mathrm{ml}$, using a fixed concentration of the mixed standards solution of biogenic amines $(5 \mathrm{mg} / \mathrm{ml})$ (Fig. 4A) and a wine sample (Fig. 4B). The effect of the concentration of derivatization reagent $\mathrm{DnsCl}$ on the peak area of each biogenic amine is presented in the graphs in Figure 4. It was found that $\mathrm{DnsCl}$ presented a similar influence on the derivatization of biogenic amines in the standard solution and the wine except for the lowest concentration of $\mathrm{DnsCl}$ in wine samples. The concentration of $\mathrm{DnsCl}$ of $10 \mathrm{mg} / \mathrm{ml}$ was chosen, giving highest peak areas for all analytes. The subsequent increase in concentration did not cause any significant changes in the peak areas of the components.

The effect of $\mathrm{pH}$ on derivatization was further investigated. The following $\mathrm{pH}$ values were tested: $8.5,9,9.5$ and 10 . The $\mathrm{pH}$ value was varied with the addition of $\mathrm{Na}_{2} \mathrm{CO}_{3}(0.4 \mathrm{M})$; the obtained results are presented in Figure 5. As can be seen,
pH 9.5 presented a lower response for spermine, spermidine, tyramine and histamine, and higher response for cadavarine, putrescine, and 2phenylethylamine, but other $\mathrm{pH}$ values tested did not have a significant effect. Taking into account the recommended working $\mathrm{pH}$ values for the column (between 2 to 10), $\mathrm{pH} 9$ was chosen as optimal for further analyses.

Optimization of time for reaction between $\mathrm{DnsCl}$ and biogenic amines is very important. To optimize the reaction time, standard solutions of each biogenic amine were prepared and derivatized after 20, 30, 4050 and 60 min (Fig. 6), followed by HPLC analysis. Derivatization time of $1 \mathrm{~h}$ was proposed as sufficient for complete derivatization reaction.

In order to test the influence of sample preparation procedures on the concentration of biogenic amines after the derivatization step, two standard solutions (5 and $10 \mathrm{mg} / \mathrm{l})$ and spiked wine sample (with 5 and $10 \mathrm{mg} / \mathrm{l}$ ) were evaporated under nitrogen flow at $40{ }^{\circ} \mathrm{C}$. The results were compared to those from the standards prepared without evaporation. Therefore, the obtained recoveries ranged from 84.9 to 97.5 for all biogenic amines except for spermidine and spermine (from 73.3 to $77.4 \%$ ) in the standard solution and from 81.8 to $90.8 \%$ (except for spermidine and spermine, from 69.5 to $71.9 \%$ ) in the spiked wine sample (data not shown) prepared with or without evaporation. These results confirmed that the evaporation step does not affect the concentration of biogenic amines and demonstrated that all biogenic amines have analogous behavior in standard solution and in the wine matrix. 

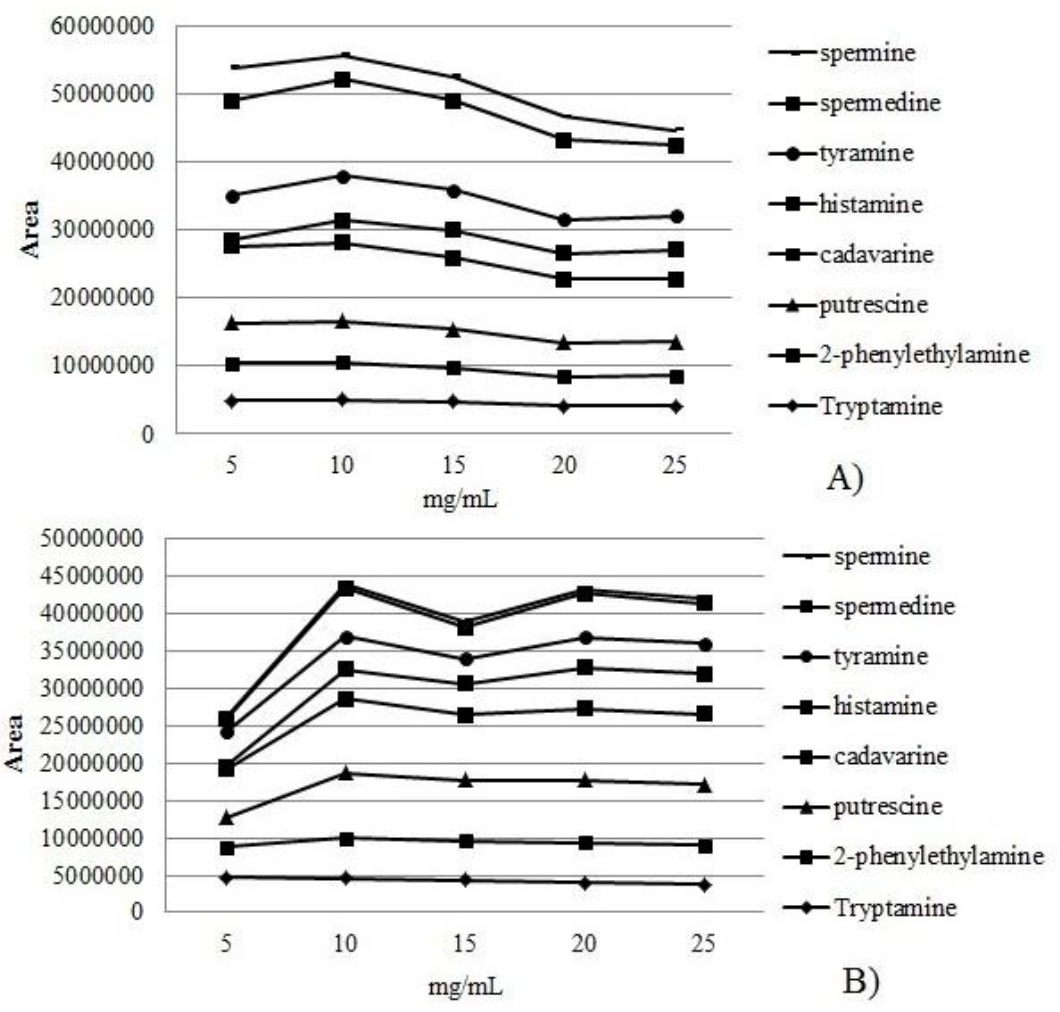

A)

Fig. 4. Influence of concentration of $\mathrm{DnsCl}$ on the peak area of each biogenic amine used with standard solution (A) and wine (B)

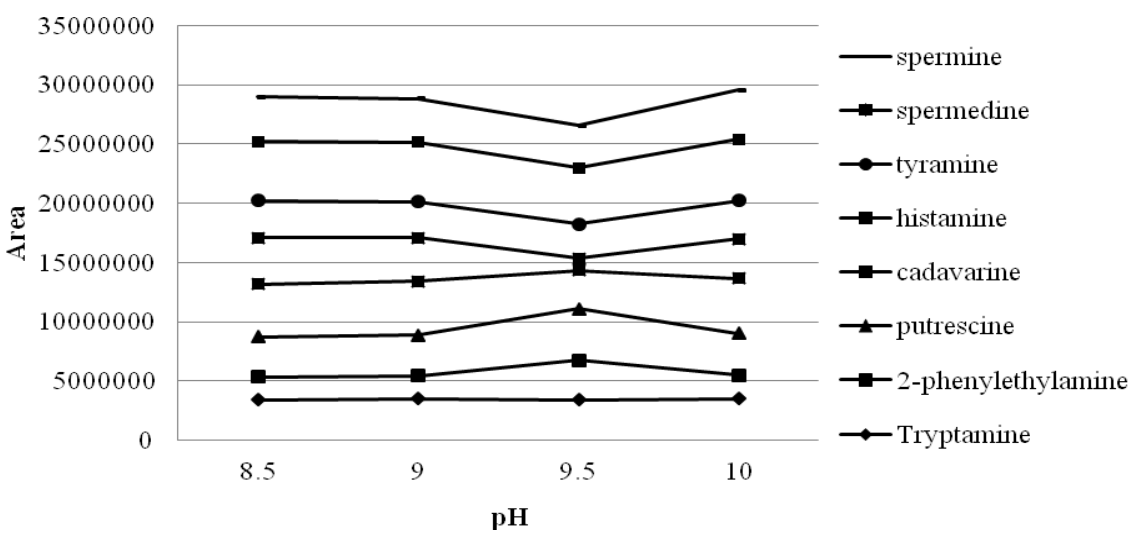

Fig. 5. Influence of $\mathrm{pH}$ of derivatization on the peak area of biogenic amines in wine

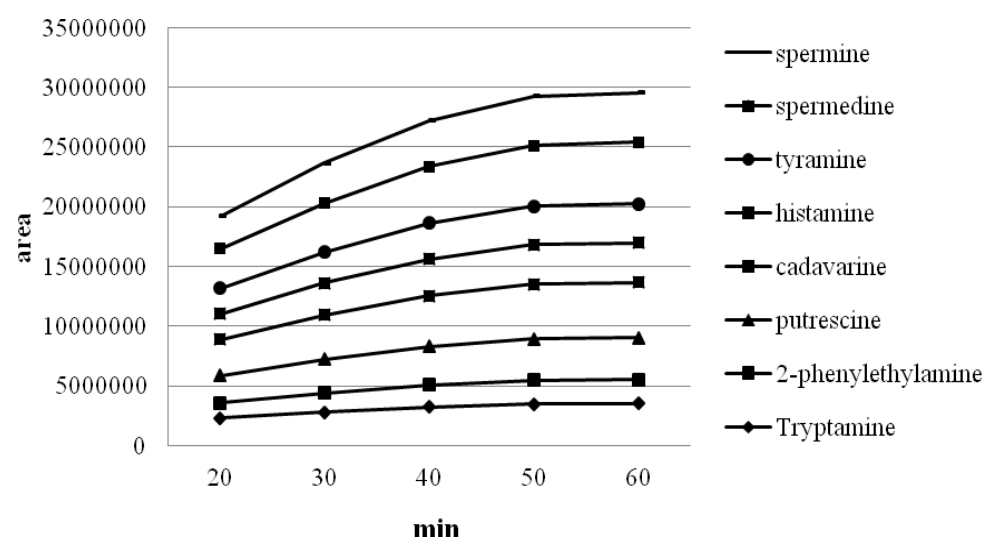

Fig. 6. Optimization of the time for derivatization in wine matrix 


\subsection{Validation of the method}

The linearity data, including slope, intercept and correlation coefficient $\left(R^{2}\right)$, are presented in Table 1 . As can be seen from the table, the linearity is satisfactory in all cases with correlation coefficients $\left(R^{2}>0.99\right)$, ranging from 0.9964 for 2-phenyletylamine to 0.9995 for spermidine and spermine.

Limit of detection (LOD) determined as a $\mathrm{LOD}=3 \times \mathrm{SD} /$ slope and limit of quantification (LOQ) determined as LOQ $=10 \times \mathrm{SD} /$ slope in a low concentration level, were calculated for all amines (Table 1).

Accuracy and precision. The intra-day and inter-day accuracy and precision were determined by injection of standard solutions with low $(0.2 \mathrm{mg} / \mathrm{l})$, medium $(5 \mathrm{mg} / \mathrm{l})$ and high concentration $(10 \mathrm{mg} / \mathrm{l})$. For determination of intra-day accuracy and precision, freshly prepared solutions were used, analyzed immediately, in 3 repetitions during one day. Interday accuracy and precision were determined during 3 consecutive days with three repeated analyses. The results are presented in Table 2.

The accuracy was expressed with a relative error of the determined concentration compared with the true (nominal) value. Satisfactory results for the relative error are lower than $20 \%$ for low concentrations and lower than $10 \%$ for high concentrations.

Table 1

Range of determination, coefficients of the regression curves (slope and intercept), correlation coefficient $\left(R^{2}\right), L O D$ and $L O Q$

\begin{tabular}{lcccccc}
\hline \hline Biogenic amines & $\begin{array}{c}\text { Calibration range } \\
(\mathbf{m g} / \mathbf{l})\end{array}$ & Slope & Intercept & $\boldsymbol{R}^{\mathbf{2}}$ & LOD & LOQ \\
\hline Tryptamine & $0.05^{-10}$ & 800648.9 & -43378.0 & 0.9979 & 0.01 & 0.04 \\
2-Phenylethylamine & $0.09^{-10}$ & 621432.4 & -35326.6 & 0.9964 & 0.03 & 0.09 \\
Putrescine & $0.05^{-10}$ & 86187.7 & -36119.9 & 0.9989 & 0.01 & 0.03 \\
Cadavarine & $0.05^{-2}$ & 1849653.5 & -84706 & 0.9988 & 0.01 & 0.03 \\
Histamine & $0.06^{-2}$ & 1097320.8 & -57324.1 & 0.9983 & 0.02 & 0.06 \\
Tyramine & $0.05^{-2}$ & 1367873 & -53868 & 0.9978 & 0.01 & 0.04 \\
Spermidine & $0.09^{-2}$ & 1996501.6 & -85383.1 & 0.9994 & 0.03 & 0.09 \\
Spermine & $0.10^{-2}$ & 1624648.5 & -65967.1 & 0.9995 & 0.05 & 0.10 \\
\hline \hline
\end{tabular}

T a b l e 2

Inter- and intra-day accuracy and precision

\begin{tabular}{|c|c|c|c|c|c|c|c|c|c|c|c|c|}
\hline \multirow{3}{*}{$\begin{array}{l}\text { Biogenic } \\
\text { amines }\end{array}$} & \multicolumn{12}{|c|}{ The content of standard addition in wine } \\
\hline & \multicolumn{4}{|c|}{$0.2 \mathrm{mg} / \mathrm{l}$} & \multicolumn{4}{|c|}{$5 \mathrm{mg} / \mathrm{l}$} & \multicolumn{4}{|c|}{$10 \mathrm{mg} / \mathrm{l}$} \\
\hline & $\langle x\rangle$ & SD & $\begin{array}{l}R S D \\
(\%) \\
\end{array}$ & $e_{R}$ & $\langle x\rangle$ & SD & $\begin{array}{l}R S D \\
(\%)\end{array}$ & $e_{R}$ & $\langle x\rangle$ & $\mathrm{SD}$ & $\begin{array}{l}R S D \\
(\%)\end{array}$ & $e_{R}$ \\
\hline \multicolumn{13}{|c|}{ Inter-day accuracy and precision (3 replicates in one day) } \\
\hline TRP & 0.23 & 0.02 & 9.91 & 4 & 4.57 & 0.27 & 5.98 & -10 & 9.97 & 0.08 & 0.79 & -1 \\
\hline PEA & 1.45 & 0.09 & 5.98 & -10 & 5.91 & 0.55 & 9.26 & -10 & 10.3 & 0.29 & 2.84 & -1 \\
\hline PUT & 2.56 & 0.07 & 2.65 & -9 & 6.98 & 0.28 & 4.05 & -7 & 12.5 & 0.36 & 2.89 & 2 \\
\hline CAD & 0.34 & 0.03 & 8.96 & -12 & 4.50 & 0.37 & 8.19 & -8 & 10.2 & 0.15 & 1.51 & -9 \\
\hline HIST & 0.41 & 0.04 & 9.47 & -16 & 4.48 & 0.44 & 9.92 & -7 & 10.2 & 0.04 & 0.43 & -3 \\
\hline TYR & 0.99 & 0.06 & 5.72 & -12 & 5.30 & 0.51 & 9.57 & -13 & 10.6 & 0.23 & 2.20 & -6 \\
\hline SPD & 0.17 & 0.01 & 8.32 & -19 & 4.29 & 0.39 & 9.03 & -9 & 9.88 & 0.13 & 1.32 & -5 \\
\hline SPM & 0.14 & 0.01 & 7.21 & -18 & 4.55 & 0.33 & 7.33 & -10 & 8.92 & 0.63 & 7.05 & -4 \\
\hline \multicolumn{13}{|c|}{ Intra-day accuracy and precision (3 replicates in 3 different days) } \\
\hline TRP & 0.23 & 0.03 & 12.52 & 1 & 4.56 & 0.34 & 7.40 & -9 & 9.94 & 0.14 & 1.41 & 0 \\
\hline PEA & 1.50 & 0.07 & 4.81 & -1 & 5.87 & 0.44 & 7.50 & -10 & 11.2 & 0.05 & 0.47 & -8 \\
\hline PUT & 2.51 & 0.04 & 1.64 & 6 & 6.81 & 0.66 & 9.73 & -9 & 12.3 & 0.21 & 1.67 & 0 \\
\hline CAD & 0.34 & 0.03 & 8.96 & 3 & 4.50 & 0.30 & 6.73 & -8 & 9.47 & 0.41 & 4.28 & -2 \\
\hline HIST & 0.41 & 0.04 & 9.47 & 6 & 4.57 & 0.35 & 7.71 & -10 & 10.2 & 0.16 & 1.61 & 0 \\
\hline TYR & 1.00 & 0.07 & 6.57 & -5 & 5.15 & 0.49 & 9.60 & -9 & 10.3 & 0.24 & 2.30 & -3 \\
\hline SPD & 0.18 & 0.01 & 7.88 & -20 & 3.94 & 0.19 & 4.84 & -7 & 9.75 & 0.42 & 4.36 & -2 \\
\hline SPM & 0.17 & 0.01 & 6.94 & -20 & 4.13 & 0.16 & 3.76 & -11 & 9.65 & 0.58 & 6.02 & -8 \\
\hline
\end{tabular}

$\langle x\rangle$ - average, $\mathrm{SD}$ - standard deviation, $R S D$ - relative standard deviation, $e_{R}-$ relative error 
Precision was expressed as a relative standard deviation $(R S D)$. Satisfactory results for $R S D$ are lower than $20 \%$ for low concentrations and lower than $10 \%$ for high concentrations.

The relative errors for inter-day and intra-day accuracy and precision ranged between -19 and $4 \%$ and between -20 and $6 \%$, respectively. The relative errors were highest $(-20 \%)$ for spermine and spermidine but only for the lowest standard addition ( 0.2 $\mathrm{mg} / \mathrm{l}$ ), so the results confirmed that the developed method is accurate and convenient for quantitative analysis of biogenic amines.

The accuracy of the method was also checked using the standard addition method on real wine samples. One wine sample was spiked at three concentration levels with mixed standard solutions of biogenic amines with low $(0.2 \mathrm{mg} / \mathrm{l})$, medium $(5 \mathrm{mg} / \mathrm{l})$ and high $(10 \mathrm{mg} / \mathrm{l})$ concentrations. The analysis of these spiked samples led to calculated recoveries ranging between 70 and 105 $\%$ (Table 3), which confirmed the accuracy of the method and its suitability for the analysis of biogenic amines in wine samples.

Repeatability and reproducibility. Repeatability was checked with 6 repetitions in one day, while reproducibility was checked with 3 repetitions in 5 consecutive days, both performed on real wine samples (Table 4). Values for the relative standard deviation were very low, ranging from 3.80 to $11.7 \%$ for repeatability and 5.97 to $15.8 \%$ for reproducibility, confirming that the method is accurate and can be applied for the determination of biogenic amines in white and red wines.

Table 3

Standard additions method for checking the accuracy on real samples

\begin{tabular}{cccccccc}
\hline \hline \multirow{2}{*}{$\begin{array}{c}\text { Biogenic } \\
\text { amines }\end{array}$} & $\begin{array}{c}\text { Found without } \\
\text { addition }\end{array}$ & \multicolumn{2}{c}{$0.2 \mathrm{mg} / \mathrm{l}$} & \multicolumn{2}{c}{$5 \mathrm{mg} / \mathrm{l}$} & \multicolumn{2}{c}{$10 \mathrm{mg} / \mathrm{l}$} \\
\cline { 3 - 8 } & Found mg/l & $\begin{array}{c}\text { Recovery } \\
\%\end{array}$ & Found mg/l & $\begin{array}{c}\text { Recovery } \\
\%\end{array}$ & Found mg/l & $\begin{array}{c}\text { Recovery } \\
\%\end{array}$ \\
\hline TRP & 0.02 & 0.23 & 105 & 4.56 & 91 & 9.96 & 99 \\
PEA & 1.29 & 1.45 & 82 & 5.76 & 90 & 11.2 & 99 \\
PUT & 2.42 & 2.56 & 96 & 7.14 & 96 & 12.5 & 102 \\
CAD & 0.16 & 0.31 & 78 & 4.63 & 89 & 9.40 & 92 \\
HIST & 0.22 & 0.52 & 99 & 4.77 & 89 & 10.0 & 97 \\
TYR & 0.82 & 0.99 & 82 & 5.22 & 88 & 10.3 & 94 \\
SPD & 0.02 & 0.17 & 77 & 3.69 & 74 & 9.52 & 95 \\
SPM & n.d & 0.14 & 72 & 3.55 & 71 & 9.60 & 96 \\
\hline \hline
\end{tabular}

Table 4

Results for repeatability and reproducibility of biogenic amines $(\mathrm{mg} / \mathrm{l})$ in wine

\begin{tabular}{|c|c|c|c|c|c|c|c|c|}
\hline Samples & TRP & PEA & PUT & CAD & HIST & TYR & SPD & SPM \\
\hline Red wine & \multicolumn{8}{|c|}{ Repeatability (6 replicates in one day) } \\
\hline$\langle x\rangle$ & 0.02 & 1.29 & 2.42 & 0.16 & 0.22 & 0.82 & 0.02 & n.d \\
\hline SD & 0.00 & 0.09 & 0.20 & 0.02 & 0.02 & 0.03 & 0.00 & n.d \\
\hline$R S D(\%)$ & 7.06 & 7.34 & 8.41 & 11.7 & 11.1 & 3.80 & 11.8 & n.d \\
\hline Red wine & \multicolumn{8}{|c|}{ Reproducibility $(3$ replicates $\times 5$ days $)$} \\
\hline$\langle x\rangle$ & 0.02 & 1.33 & 2.51 & 0.15 & 0.22 & 0.78 & 0.02 & n.d \\
\hline SD & 0.00 & 0.12 & 0.15 & 0.01 & 0.02 & 0.08 & 0.00 & n.d \\
\hline$R S D(\%)$ & 5.97 & 8.63 & 5.93 & 9.08 & 9.09 & 10.2 & 15.8 & n.d \\
\hline
\end{tabular}

$\langle x\rangle$ - average in $\mathrm{mg} / \mathrm{l}, \mathrm{SD}$ - standard deviation, $R S D$ - relative standard deviation

\subsection{Application of the method on wine samples analysis}

The optimized and validated HPLC method, after derivatization of biogenic amines with $\mathrm{DnsCl}$, was applied to the analysis of white and red wines of Macedonian origin. The content of the tested biogenic amines in the wines is presented in Table 5.
Comparing the total amount of biogenic amines, it was concluded that red wines contained a higher content $(28.8 \mathrm{mg} / \mathrm{l}$, on average) compared to white wines (14.5 mg/l, on average). In general, wines having undergone malolactic fermentation usually have higher levels of amines as was found here for the red wines. 
Table 5

Content of biogenic amines in Macedonian wines given in $m g / l \pm$ standard deviation $(n=3)$

\begin{tabular}{|c|c|c|c|c|c|c|c|c|c|}
\hline & TRP & PEA & PUT & CAD & HIST & TYR & SPD & SPM & $\begin{array}{l}\text { Total } \\
\text { con- } \\
\text { tent }\end{array}$ \\
\hline \multicolumn{10}{|l|}{ White wine } \\
\hline Muscat & $1.20 \pm 2.14$ & $\leq \mathrm{LOQ}$ & $7.01 \pm 0.09$ & $0.21 \pm 0.03 \mathrm{a}$ & $\leq \mathrm{LOQ}$ & $0.09 \pm 0.05 \mathrm{a}, \mathrm{c}$ & n.d & n.d & 8.51 \\
\hline Risling & $4.99 \pm 1.20$ & $0.93 \pm 0.05 \mathrm{a}$ & $8.20 \pm 0.36$ & n.d & $1.01 \pm 0.08 \mathrm{a}$ & $0.13 \pm 0.04 \mathrm{c}$ & $0.13 \pm 0.09$ & n.d & 15.4 \\
\hline Smederevka & $5.30 \pm 3.25 \mathrm{a}$ & $11.1 \pm 0.26$ & $0.37 \pm 0.10 \mathrm{a}$ & $0.19 \pm 0.03 \mathrm{a}$ & $\leq \mathrm{LOQ}$ & $0.23 \pm 0.05 b$ & $\leq \mathrm{LOQ}$ & n.d & 17.2 \\
\hline Sauvi. Blanc & $5.60 \pm 1.78 \mathrm{a}$ & n.d & n.d & n.d & $0.16 \pm 0.02$ & $0.09 \pm 0.06 \mathrm{a}$ & $\leq \mathrm{LOQ}$ & $\leq \mathrm{LOQ}$ & 5.85 \\
\hline Žilavka & $9.62 \pm 2.94$ & $12.2 \pm 0.28$ & $0.57 \pm 0.29 \mathrm{a}$ & $0.20 \pm 0.07 \mathrm{a}$ & n.d & $0.19 \pm 0.18 \mathrm{~b}$ & $\leq \mathrm{LOQ}$ & n.d & 22.8 \\
\hline Chardonnay & $5.75 \pm 1.39 \mathrm{a}$ & $1.63 \pm 0.63 \mathrm{a}$ & $8.68 \pm 0.57$ & $0.13 \pm 0.04 \mathrm{a}$ & $1.05 \pm 1.12 \mathrm{a}$ & $0.21 \pm 0.04 \mathrm{~b}$ & $\leq \mathrm{LOQ}$ & n.d & 17.5 \\
\hline \multicolumn{10}{|l|}{ Red wine } \\
\hline Plavac & $6.29 \pm 2.90 \mathrm{~b}$ & $2.46 \pm 0.06 \mathrm{~b}, \mathrm{c}$ & $10.5 \pm 0.29 \mathrm{cb}$ & $0.73 \pm 0.20 \mathrm{~b}$ & $0.48 \pm 0.05$ & $6.15 \pm 0.08$ & $0.21 \pm 0.09 \mathrm{a}$ & n.d & 26.8 \\
\hline Pinot Noir & $7.98 \pm 0.22$ & $1.69 \pm 0.44$ & $10.3 \pm 0.06 \mathrm{~b}$ & $0.06 \pm 0.06$ & $0.07 \pm 0.01$ & $1.29 \pm 0.28$ & $0.04 \pm 0.04 \mathrm{~b}$ & $1.67 \pm 0.25$ & 23.1 \\
\hline Vranec & $6.69 \pm 1.90 \mathrm{~b}$ & $2.17 \pm 0.11 \mathrm{c}$ & $15.6 \pm 0.54$ & $0.63 \pm 0.14 \mathrm{~b}$ & $4.07 \pm 0.22 b$ & $1.99 \pm 0.08$ & n.d & $0.62 \pm 0.21$ & 31.8 \\
\hline Caber. Sauv. & $5.01 \pm 0.54$ & $15.0 \pm 0.29$ & $11.1 \pm 0.47 \mathrm{c}$ & $0.12 \pm 0.02$ & $4.04 \pm 0.09 \mathrm{~b}$ & $4.30 \pm 0.21$ & $0.10 \pm 0.04$ & $0.85 \pm 0.20$ & 40.5 \\
\hline Kadarka & $3.18 \pm 2.31 \mathrm{c}$ & $4.10 \pm 1.85$ & $16.6 \pm 9.41 \mathrm{~d}$ & $0.36 \pm 0.06$ & $1.53 \pm 1.49$ & $0.12 \pm 0.05 \mathrm{~d}$ & $0.06 \pm 0.05 b$ & n.d & 25.9 \\
\hline Kratošija & $3.76 \pm 1.03 \mathrm{c}$ & $2.81 \pm 0.17 \mathrm{~b}$ & $13.3 \pm 227$ & $0.61 \pm 0.1 \mathrm{~b}$ & $0.21 \pm 0.14 \mathrm{c}$ & n.d & n.d & $1.05 \pm 0.28$ & 21.7 \\
\hline
\end{tabular}

n.d = not detected; $\leq$ LOQ means value lower than the limit of quantification; same letters in the column indicate values that are not significantly different $(p>0.05)$, analyzed by the ANOVA Tukey-Kramer Multiple Comparisons Test.

Histamine was the main biogenic amine present in a higher content as a result of that fermentation. Moreover, the levels of biogenic amines depending on the free amino acid content (i.e. biogenic amines increase with increase in amino acids). Grape variety, geographical region, vintage as well as vinification methods also influence the levels of amino acids in grapes, and then in the corresponding wine [25]. In our wines, histamine was found in all red wines, ranging from 0.07 to $4.07 \mathrm{mg} / \mathrm{l}$, which is lower than the upper limits established in Belgium $(6 \mathrm{mg} / \mathrm{l})$, in France $(8 \mathrm{mg} / \mathrm{l})$ or in Switzerland $(10 \mathrm{mg} / \mathrm{l})$ [7, 8]. In the Republic of Macedonia, the maximal content of biogenic amines in wines has not yet been officially established. The biogenic amines that have toxicological effects (HIST, TYR, TRP and PEA) [9, 12, 16, 17, 25] were in the ranges: $1.20-9.62 \mathrm{mg} / \mathrm{l}$ for TYR, $0.07-4.30 \mathrm{mg} / \mathrm{l}$ for HIST, $0.93-15.0 \mathrm{mg} / \mathrm{l}$ for PEA and $1.20-9.40 \mathrm{mg} / \mathrm{l}$ for TRP. PUT and CAD were also found in red wines at higher concentrations than in white wines and the quantities were in the following ranges: PUT: $10.3 \mathrm{mg} / \mathrm{l}$ to $16.6 \mathrm{mg} / \mathrm{l}$ for red wines and 0.37 to $8.68 \mathrm{mg} / \mathrm{l}$ for white wines; and CAD: 0.06 to $1.26 \mathrm{mg} / \mathrm{l}$ and 0.13 to $0.21 \mathrm{mg} / \mathrm{l}$ for the red and white wines, respectively. SPD and SPM were present in low ranges for red wines $(0.04-0.21 \mathrm{mg} / \mathrm{l}$ and 0.62 to $1.25 \mathrm{mg} / \mathrm{l}$, respectively), while in white wines, SPD was detected only in Riesling wine and SPM was not quantified. These results are similar to other reported results for biogenic amines in wines $[5,21,25]$.
In general, all wines contained low amounts of biogenic amines that were lower than the settled maximal concentrations allowed, especially evident for histamine, which is considered a compound that causes headaches and migraines after consuming red wine, suggesting that all of the analyzed Macedonian wines are safe for human consumption.

\section{CONCLUSIONS}

A fast and accurate method for analysis of the biogenic amines tryptamine (TRP), putrescine (PUT), histamine (HIST), phenylethylamine (PEA), tyramine (TYR), cadaverine (CAD), spermidine (SPD), spermine (SPM) in wines was developed and validated. The method presented satisfactory separation of the analytes, good linearity, sensitivity, precision and accuracy. The developed and validated method was used for determination of these biogenic amines in Macedonian red and white wines. Red wines presented a higher content of amines compared to white wines. All wines contained biogenic amines in a concentration that was lower than the maximal allowed.

\section{REFERENCES}

[1] A. Lonvaud-Funel, Biogenic amines in wines: role of lactic acid bacteria, FEMS Microbiology Letters, 199, 913 (2001).

[2] V. M. Moreno-Arribas, M. C. Polo, Winemaking Biochemistry and microbiology: Current knowledge and fu- 
ture trends. Critical Reviews in Food Science and Nutrition, 45, 265-286 (2005).

[3] J. M. Landete, S. Ferrer, I. Pardo, Biogenic amine production by lactic acid bacteria, acetic bacteria and yeast isolated from wine. Food Control, 103(4), 1475-1486 (2007).

[4] R. Romero, D. Gázquez, M. G. Bagur, M. SánchezVinas, Optimization of chromatographic parameters for the determination of biogenic amines in wines by reversed-phase high-performance liquid chromatography, Journal of Chromatography A, 871, 75-83 (2000).

[5] C. Proestos, P. Loukatos, M. Komaitis, Determination of biogenic amines in wines by HPLC with precolumdansylation and fluorimetric detection, Food Chemistry, 106, 1218-1224 (2008).

[6] E. Soufleros, M. L.Barrios, A. Bertrand, Correlation between the content of biogenic amines and other wine compounds, American Journal of Enology and Viticulture, 49, 266-278 (1998).

[7] K. D. Millies, D. Zimlich, Histamingehalte von Weinen und Schaumweinen. Weinwirtschaft- Technik, 1, 21-24 (1988.)

[8] P. Lehtonen, Determination of amines and amino acids in wine - a review. Am. J. Enol. Vitic. 47, 127-133 (1996).

[9] Z. Loukou, A. Zotou, Determination of biogenic amines as dansyl derivatives in alcoholic beverages by highperformance liquid chromatography with fluorimetric detection and characterization of the dansylated amines by liquid chromatography-atmospheric pressure chemical ionization mass spectrometry, Journal of Chromatography A, 996, 103-113 (2003).

[10] A. Lonvaud-Funel, Biogenic amines in wines: Role of lactic acid bacteria. FEMS Microbiology Letters, 199, 913 (2001).

[11] L. Arce, L. Rios, M. Valcarel, Direct determination of biogenic amines in wine by intergrating continuous flow clean-up and capillary electrophoresis with indirect UV detection. Journal of Chromatography A, 803, 249-260 (1998).

[12] B. M. De Borba, J. S. Rohrer, Determination of biogenic amines in alcoholic beverages by ion chromatography with suppressed conductivity detection and integrated pulsed amperometric detection. Journal of Chromatography, 1155, 22-30 (2007).

[13] S. Santos, Biogenic amines: their importance in foods, Journal of Food Microbiology, 29, 213-231(1996).
[14] L. Yongmei, L. Xin, C. Xiaohong, J. Mei, L Chao, D. Mingsheng, A survey of biogenic amines in Chinese rice wines, Food Chemistry, 100, 1424-1428 (2007).

[15] A. Moreno-Arribas, M. C. Polo, F. Jorganes, R. Munoz, Screening of biogenic amine production by lactic acid bacteria isolated from grape must and wine, International Journal of Food Microbiology, 84, 117-123 (2003).

[16] G. Mo. Dugo, F. Vilasi, G. L. La Torre, T. M. Pellicano', Reverse phase HPLC/DAD determination of biogenic amines as dansyl derivatives in experimental red wines, Food Chemistry, 95, 672-676 (2006).

[17] S. Millán, C. Sampedro, N. Unceta, A. M. Goicolea, J. R. Barrio, Simple and rapid determination of biogenic amines in wine by liquid chromatography - electrospray ionization ion trap mass spectrometry, Analytica Chimica Acta, 584, 145-152 (2007).

[18] J. Gafner, 32nd Annual; New York Wine Industry Workshop. Biogenic amines in wine, Proceedings of the 13th International Enology Symposium in Montpellier, France, 95-106, 2002.

[19] A. Marcobal, B. de Rivas, R. Muñoz, Methods for the detection of bacteria producing biogenic amines on foods: A Survey, Journal of Consumer Protection and Food Safety, 187-196 (2006)

[20] J. T. Littlewood, C. Gibbs, V. Glover, M. Sandler, P. T. G. Davies, F. Rose, Red wine as a cause of migraine, Lancet, 1(8585), 558-559 (1988).

[21] R. E. Anli, N. Vural, S. Yilmaz, Y. H. Vural, The determination of biogenic amines in Turkish red wines. Journal of Food Composition and Analysis, 17, 53-62 (2004).

[22] M. C. Vidal-Carou, F. Lahoz-Portoles, S. Bover-Cid, A. Marine-Font, Ion-pair high-performance liquid chromatographic determination of biogenic amines and polyamines in wine and other alcoholic beverages, Journal of Chromatography A, 98, 235-241 (2003).

[23] A. Sass-Kiss, E. Szerdahelyi, G. Hajós, Study of biologically active amines in grape and wines by HPLC, Chromatographia Supplement 51, 316-320 (2000).

[24] N. Garcia-Villar, J. Saurina, S. Hernandez-Cassou, High-performance liquid chromatographic determination of biogenic amines in wines with an experimental design optimization procedure, Analytica Chimica Acta, 575, 97-105 (2006).

[25] A. Y. Smit1, W. J. du Toit, M. du Toit, Biogenic amines in wine: Understanding the headache, South African Journal for Enology and Viticulture, 29(2) 109-127, (2008). 